\title{
Ecological and financial impacts of illegal bushmeat trade in Zimbabwe
}

\author{
P. A. Lindsey, S. S. Romañach, C. J. Tambling, K. Chartier and R. Groom
}

Abstract Under conditions of political instability and economic decline illegal bushmeat hunting has emerged as a serious conservation threat in Zimbabwe. Following settlement of game ranches by subsistence farming communities, wildlife populations have been eradicated over large areas. In several areas still being managed as game ranches illegal hunting is causing further declines of wildlife populations (including threatened species such as the wild dog Lycaon pictus and black rhinoceros Diceros bicornis), threatening the viability of wildlife-based land uses. From August 2001 to July 2009 in Savé Valley Conservancy 10,520 illegal hunting incidents were recorded, 84,396 wire snares removed, 4,148 hunters caught, 2,126 hunting dogs eliminated and at least 6,454 wild animals killed. Estimated future financial losses from illegal hunting in the Conservancy exceed USD 1.1 million year ${ }^{-1}$. Illegal hunters' earnings account for $0.31-0.52 \%$ of the financial losses that they impose and the bushmeat trade is an inefficient use of wildlife resources. Illegal hunting peaks during the late dry season and is more frequent close to the boundary, near areas resettled during land reform and close to water. Illegal hunting with dogs peaks during moonlight periods. Our study highlights several management and land-use planning steps required to maximize the efficacy of anti-poaching and to reduce the likelihood of high impacts of illegal hunting. Anti-poaching efforts should be aligned with the regular temporal and spatial patterns of illegal hunting. Leases for hunting and tourism concessions should ensure minimum adequate investment by operators in anti-poaching. Reserve designers should minimize the surface area to volume ratio of parks. Fences should not be constructed using wire that can be made into snares. Land reform involving game ranches should integrate communities in wildlife-based land uses

P.A. LINDSEY ${ }^{*}$ (Corresponding author) and R. Groom Mammal Research Institute, Department of Zoology and Entomology, University of Pretoria, Pretoria 0002, South Africa, and African Wildlife Conservation Fund, 10564NW, 57th Street, Doral, FL33178 Florida, USA. E-mail palindsey@ gmail.com

S.S. RomañaCH African Wildlife Conservation Fund, Doral, USA

C.J. Tambling Centre for African Conservation Ecology, Department of Zoology, Nelson Mandela Metropolitan University, Port Elizabeth, South Africa

K. Chartier University of Florida, Davie, Florida, USA

*Also at: TRAFFIC East/Southern Africa, PO Box CY1409, Causeway, Harare, Zimbabwe

Received 4 July 2009. Revision requested 7 September 2009.

Accepted 16 October 2009. and ensure spatial separation between land for wildlife and human settlement. Means are required to create stakeholdings for communities in wildlife and disincentives for illegal hunting.

Keywords Fences, game ranching, land reform, poaching, private land, Savé Valley Conservancy, snaring, Zimbabwe

This paper contains supplementary material that can be found online at http://journals.cambridge.org

\section{Introduction}

There has been increasing focus in Africa on the 1 conservation threat posed by the bushmeat trade, particularly in the forest regions of Central and West Africa (Noss, 1998; Wilkie et al., 1998; Bowen-Jones \& Pendry, 1999; Barnes, 2002; Fa et al., 2002; Robinson \& Bennett, 2004; Bennett et al., 2007). Encroachment on natural habitats and increasing human populations are resulting in enhanced access to wildlife resources and elevated offtake by bushmeat hunters. The bushmeat trade is a severe threat to wildlife populations in Central and West Africa (Fa et al., 2002) and the impacts are exacerbated in some areas by the use of unselective and wasteful hunting methods such as cable snares (Noss, 1998). At current rates of offtake widespread local extinctions of forest species are imminent (Wilkie \& Carpenter, 1999). In West and Central Africa bushmeat hunting is a survival strategy for large numbers of people, sometimes comprising most animal protein consumed and contributing significantly to household incomes (Wilkie \& Carpenter, 1999). Finding solutions to address unsustainable offtake is thus crucial from both conservation and development perspectives (Fa et al., 2002).

Some research has been conducted on the bushmeat trade in East Africa, notably in Serengeti (Loibooki et al., 2002; Ndibalema \& Songorwa, 2007) and parts of Kenya (Okello \& Kiringe, 2004; Wato et al., 2006). In Serengeti snaring has driven population declines of several resident species and results in significant offtake of migratory wildebeest Connochaetes taurinus and zebra Equus quagga (Loibooki et al., 2002). There has been little research on the bushmeat trade in Southern Africa and information on the topic is limited primarily to a single review (Barnett, 1998) and insights into the trade in Zambia (e.g. Lewis, 2007) and Namibia (Vaughan \& Long, 2007). This lack of attention is 
despite indications that the trade poses a severe threat to wildlife populations in parts of the region. Even in parts of comparatively affluent countries such as South Africa and Botswana illegal bushmeat hunting is a significant conservation threat (Barnett, 1998; Bushmeat Crisis Africa, 2004). However, bushmeat hunting probably has more severe impacts in poorer countries and in those with high human population densities. In Zambia and Malawi, for example, snaring for bushmeat has resulted in the depletion of wildlife populations from several protected areas (Barnett, 1998; Mulombwa, 1998).

Impacts are likely to be most severe under conditions of political instability. For example, bushmeat hunting during and immediately after the civil war (1977-1992) resulted in the virtual extirpation of wildlife populations from some Mozambican national parks (Cumming, 2004). Similarly, preliminary assessments from Zimbabwe indicate that recent political instability has been associated with a significant increase in illegal bushmeat hunting (du Toit, 2004). However, lack of reliable data on the bushmeat trade in Zimbabwe and elsewhere in southern Africa means that the problem does not receive adequate attention from conservationists, governments or policy makers. To help address this we designed a study to investigate the scale and impacts of the bushmeat trade using Savé Valley Conservancy in the South-East Lowveld of Zimbabwe as a case study.

During the 1980 s and 1990 s wildlife ranching developed as a major land use in the South-East Lowveld. In several areas ranchers cooperated to form large collaboratively managed wildlife areas or conservancies. Most notable is the $3,450-\mathrm{km}^{2}$ Savé Valley Conservancy, created in 1991 from 18 former cattle ranches. On creation of the Conservancy all internal fencing was removed and a double 350$\mathrm{km}$ perimeter game fence was constructed. Approximately 3,950 animals of 14 species were reintroduced and a security system was established, including ranch-based antipoaching teams to control illegal hunting. Wildlife abundance and diversity increased rapidly during the 1990s, as did financial returns from photographic tourism and legal safari hunting (Lindsey et al., 2009). However, these trends were reversed in 2000-2001 with the onset of the fast-track land reform programme. Nine properties in the south of the Conservancy (comprising $33 \%$ of the total land area) were settled by subsistence farmers and c. $80 \mathrm{~km}$ of $3-\mathrm{m}$ twin perimeter game fences were removed. Properties in the north of the Conservancy were not settled. The onset of large-scale bushmeat hunting coincided with the settlement process. According to the laws of Zimbabwe such hunting is illegal. The Parks and Wildlife Act (1975) and the Trapping of Animals (Control) Act (2002) state that unauthorized hunting on private land, the use of snares for hunting and the possession or sale of meat resulting from unauthorized hunting are prohibited.
The land reform process occurred during a period of pronounced political instability and contributed directly to steep economic decline. These conditions resulted in a greater reliance of people on natural resources for survival and increased access to private wildlife areas. Most game ranches in the South-East Lowveld were settled, causing a widespread shift in land use from wildlife-ranching to subsistence farming (Lindsey et al., 2009).

\section{Methods}

\section{Data collection}

From August 2005 to July 2009 illegal hunting data were collected from the individual in charge of anti-poaching on each ranch in Savé Valley Conservancy, once per month, using a standard incident report form (including number of illegal hunting incidents, number of hunters and dogs, number caught, or shot in the case of dogs, and how they were caught, number of snares recovered, number/species/ gender/age of animals killed in each incident and the status of carcasses; i.e. recovered by illegal hunters, recovered by ranch, rotten/scavenged). Data on animals killed included records of observations of carcasses in snares, carcasses found in the possession of hunters, at their homes or in hunting camps, or from identifiable hair or body parts left in snares. The location of illegal hunting incidents was indicated by the anti-poaching managers on 1:50,000 maps using $1-\mathrm{km}^{2}$ grid squares, management roads, artificial water points, hills and other natural features overlaid on the maps. Anti-poaching managers found it easy to denote the location of the incidents, and associated average error is probably $<_{1} \mathrm{~km}$.

On ranches settled during land reform collection of hunting data was only possible in the minority of areas that were still patrolled by anti-poaching game scouts (Fig. 1). The collection of data was halted from one property (Potential Ranch, owned by the government) after it became apparent that game scouts were falsifying reports and engaging in illegal hunting. During informal discussions scouts on Potential indicated they are forced to hunt to survive because of inadequate salaries and erratic payment. Potential makes up $4.2 \%$ of the Conservancy and so illegal hunting data recorded elsewhere in the Conservancy were conservatively adjusted by 1.042 (except for data on hunters caught and dogs shot because of the lack of effective anti-poaching).

From August 2001 to July 2005 illegal hunting data were derived from the Conservancy records (compiled by the Conservator from monthly reports from each property). The type of materials used to make snares was assessed by examining samples of snares $(n=272)$ removed from 14 ranches within the Conservancy each month for 6 months (August 2005 to January 2006). Rainfall data were collected 


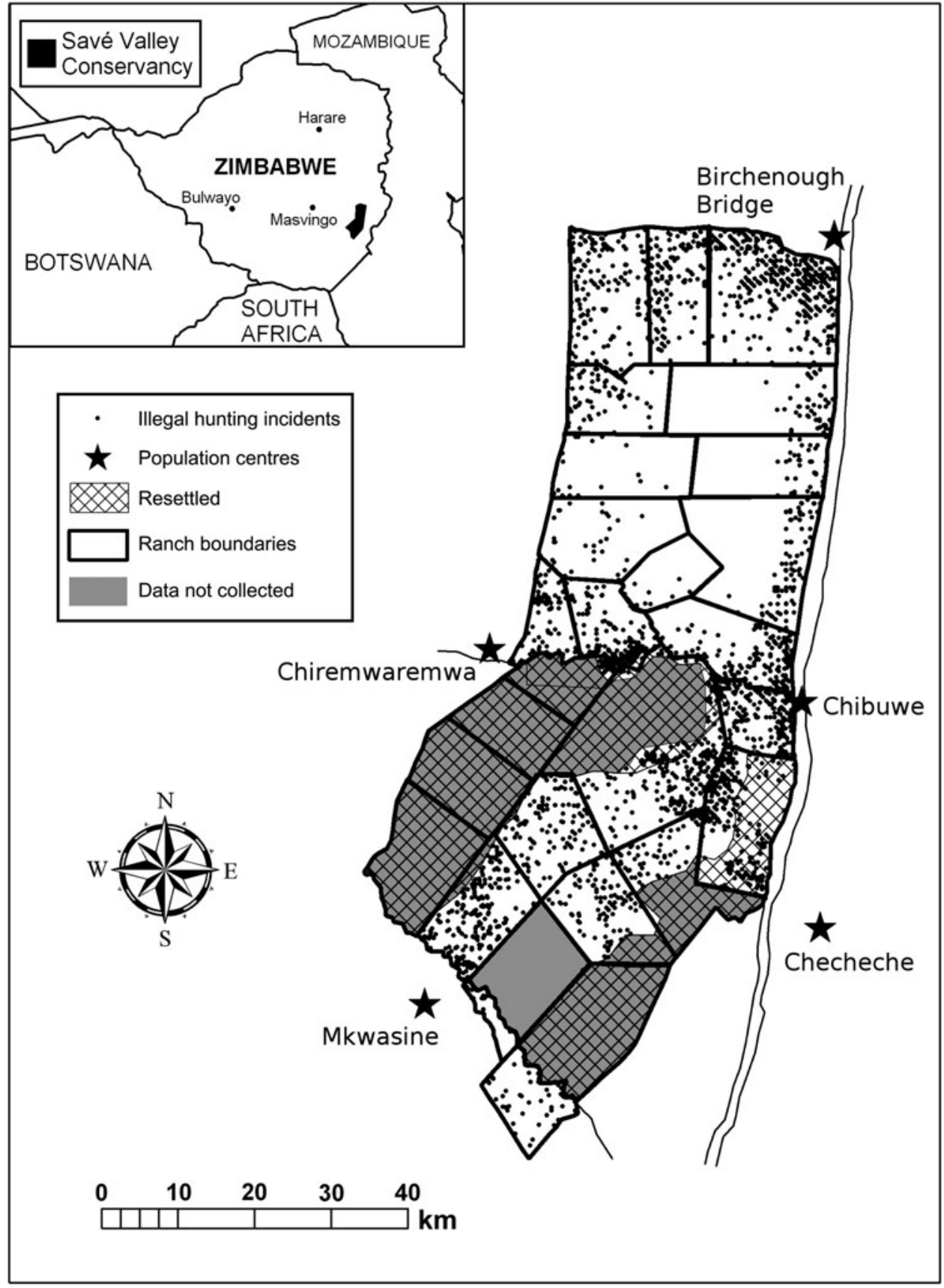

FIG. 1 Distribution of illegal hunting incidents recorded in Savé Valley Conservancy between August 2005 and July 2009. The inset shows the location of the Conservancy in Zimbabwe. from three properties located in the north, centre and south of the Conservancy.

\section{Interview survey of wildlife managers}

All of the ranchers in Savé Valley Conservancy were interviewed $(n=15)$ using a structured questionnaire designed to yield insights into anti-poaching strategies and ranchers' perceptions of the extent to which actual levels of illegal hunting exceeded the incidents detected by scouts during their patrols (Appendix 1). Several measures of investment in anti-poaching were recorded: expenditure per month, numbers and densities of scouts, scout days worked per month per $\mathrm{km}^{2}$ (recorded from January 2007 to June 2008), scout salaries, and the level of supervision, training and equipment provided to scouts.

In addition, respondents from four other wildlife areas were interviewed to obtain data on anti-poaching and on the perceived impacts of settlement and illegal hunting on wildlife populations (Chiredzi River Conservancy, $\mathrm{n}=3$; Triangle Estates, $\mathrm{n}=1$; Eaglemont Ranch, $\mathrm{n}=1$; Malilangwe Trust, $\mathrm{n}=1$ ) comprising $85.1 \%$ of the remaining private wildlife ventures in Chiredzi district (respondents from the remaining three wildlife areas were not contactable at 
the time of the study). The warden of Gonarezhou National Park (hereafter Gonarezhou) was also interviewed, as was the coordinator of a Frankfurt Zoological Society Gonarezhou management support project.

\section{Population modelling}

Leslie matrix population models were used to estimate the impact of illegal hunting on populations, taking into consideration offtake from legal safari hunting. We limited model runs to species significantly affected by illegal hunting for which accurate population estimates and data on key life-history parameters were available (Owen-Smith \& Mason, 2005): impala Aepyceros melampus, kudu Tragelaphus strepsiceros, sable Hippotragus niger, waterbuck Kobus ellipsiprymnus, warthog Phacochoerus aethiopicus, wildebeest, zebra, giraffe Giraffa camelopardalis and buffalo Syncerus caffer. The model included three age classes for each gender for each species: juveniles, subadults and adults. The models were used to track populations through yearly time steps by multiplying the population vector (i.e. numbers of each class in the population) by a transition matrix incorporating fecundity and survival values for each age/sex class (Caswell, 2001). To incorporate a possible negative influence of selective harvesting of males on the demographic structure (Gerber, 2006), we implemented a birth function of the form:

$$
B\left(n_{m}, n_{f}\right)=\frac{2 k n_{m} n_{f}}{\left(n_{m}+n_{f} h^{-1}\right)},
$$

where $k$ is the number of offspring per batch for a female, $n_{m}$ is the number of reproductive males, $n_{f}$ is the number of reproductive females and $h$ is the harem size of each male (Caswell \& Weeks, 1986). Because we were only interested in artificial regulation of populations we did not incorporate a density dependence function; any population exhibiting exponential growth was considered not to be regulated by legal or illegal hunting.

To set up the starting population structure we simulated possible historical effects of population size and safari hunting responsible for producing the current population structure. Initially, the model was run assuming a uniform age distribution (i.e. equal proportions of each age class) for 100 years, producing a stable age distribution in the absence of legal and illegal hunting. Next, a period of 12 years was simulated in which safari hunting occurred, reflecting the period 1988-1999, prior to the onset of large-scale illegal hunting. We then modelled a period where illegal hunting was included to simulate 2000-2008. The resulting age distribution was used as the basis for modelling to assess the impacts of illegal hunting.

\section{Estimating the impact of hunting on populations}

We assessed population responses to various levels of legal and illegal hunting within the north of Savé Valley Conservancy and in the portion of the south that remains under wildlife management. We do not have data on illegal hunting in the settled areas of the Conservancy (aside from the small areas that are still patrolled by scouts). However, aerial census data indicate that wildlife populations have been virtually eradicated in resettled areas and so most illegal hunting incidents probably occur on land remaining under wildlife management.

Safari hunting quotas in the Conservancy are established at constant proportions of species populations and offtake was thus kept constant for all model runs. Safari hunting is incorporated as a proportional offtake (reported hunted/ total number for each age and sex class) from the population, limited to adults and primarily males. Illegal hunting offtake was included in the model as the number of animals removed. Safari hunting was assumed to occur at 2007 levels, and two scenarios of illegal hunting were modelled: (1) with recorded losses, and (2) with losses $100 \%$ greater than recorded levels for the north of the Conservancy and $250 \%$ greater for the south (for the areas in which anti-poaching is still conducted) in 2007 (as estimated by landowners). The model was run for 15 years and the population trend recorded.

\section{The financial impacts of illegal bushmeat hunting}

Two scenarios of the historical costs of illegal hunting (from August 2005 to July 2009) are presented: (1) assuming that costs equal losses recorded in illegal hunting data, and (2) assuming that losses were 100 and $250 \%$ higher than the official data for the north and south of the Conservancy, respectively ( $161.5 \%$ higher for the Conservancy as a whole). Costs were assumed to comprise the following components:

Meat value The value of meat was estimated from the mean body mass for an individual of each species in the population, the mean percentage of body mass comprised of flesh for that species (Bothma, 2002) and the mean price that meat is sold at in the Conservancy (USD $0.60 \mathrm{~kg}^{-1}$ ) multiplied by the number of animals lost to illegal hunters.

Value of foregone safari hunts for rare and high-value species Losses of rare and high-value species to illegal hunters were assumed to result in the loss of income that could have been derived from hunting those animals as trophies. Populations of sable (c. 221 individuals), leopard Panthera pardus (population unknown), lion Panthera leo (78 individuals) and cheetah Acinonyx jubatus (population unknown) are small and trophy quotas are strictly controlled, so the loss of individuals of these species was 
assumed to result in the loss of a potential trophy. Lion, leopard, sable and cheetah are used to sell hunting packages and so the loss of individuals of those species was assumed to result in the loss of the trophy fee and the mean daily rate for hunts of those species multiplied by the mean length of hunt packages for those species (from a survey of local hunting operators' websites, $\mathrm{n}=10$ ).

Value of zebra skins Losses of zebras were assumed to result in the loss of the value of skins of that species (USD 200, mean value provided by the manager of the largest property in the Conservancy).

Safari hunting quotas During modelling we iterated populations through one-time step from $t$ to $t+1$ and assessed the difference in the number of adult males removed via legal and illegal hunting against the number of subadult males that would survive to become adult males. This gave us possible recruitment of adult males at $t+1$. This process was conducted for both the north and south of the Conservancy. If recruitment was positive, current hunting quotas were assumed to be sustainable. However, if recruitment was negative, the extent of quota reduction required to achieve a stable male population size was estimated.

Illegal rhinoceros hunting The value of rhinoceroses (Diceros bicornis and Ceratotherium simum) lost to illegal hunters in the Conservancy was assumed to equal the mean live sale value in neighbouring South Africa (Damm, 2005). Although rhinoceroses are not safari hunted in Zimbabwe, they are valuable for ecotourism.

Expenditure on anti-poaching Estimates of ranch expenditures on anti-poaching were made by managers and/or owners from each ranch in the Conservancy and by the Conservator.

\section{Statistical analyses}

A map of Savé Valley Conservancy was divided into $2 \times 2$ $\mathrm{km}$ grid cells and each cell allocated values to denote whether poaching occurred and the number and type of incidents that occurred (snaring or hunting with dogs). A multiple logistic regression model was used to identify the influence of variables on whether illegal hunting occurred in each square, including distance from the Conservancy boundary/the edge of the unsettled portion of the Conservancy, urban centres, water sources and anti-poaching effort (R Development Core Team, 2008). Anti-poaching effort was included as three categories: low $\left(<_{1}\right.$ scout day month $^{-1} \mathrm{~km}^{-2}$ ), medium (1-2) and high $(>2)$. Where logistic regression was used the final model presented comprised only significant variables included following a backwards stepwise procedure.

When testing for the relationship between patterns in illegal hunting and rainfall, data for each month were corrected in line with the variation in anti-poaching effort for that month from the mean. Anti-poaching effort was lowest during January (1.35 scout days $\mathrm{km}^{-2}$ ) and highest during July (1.85 scout days month ${ }^{-1}$ ).

\section{Results}

A total of 10,231 illegal hunting incidents (snares or snare lines, hunters' spoor, hunters' dogs, animal carcasses or illegal fishing) were recorded in Savé Valley Conservancy from August 2001 to July 2009, resulting in the loss of 6,454 individuals of 48 species (Table 1 ). One property in the south of the Conservancy (the $25-\mathrm{km}^{2}$ Hippo Haven) was able to provide data on the frequency of illegal hunting incidents prior to the settlement of adjacent land: in 1998 and 1999, 1.16 and 0.68 snares $\mathrm{km}^{-2}$ year ${ }^{-1}$, respectively, were removed from the property compared to 89.8 snares $\mathrm{km}^{-2}$ year $^{-1}$ from August 2005 to July 2009.

Anti-poaching resulted in the capture of 4,148 illegal hunters, the destruction of 2,126 hunting dogs and the removal of 84,396 wire snares. Sixty-three percent (63.4\%) of illegal hunting incidents involved snares, $31.7 \%$ involved hunting with dogs, $0.03 \%$ involved firearms and $4.5 \%$ involved illegal fishing. Snares had a mean length of 3.43 $\pm 0.94 \mathrm{~m}$ and were made of $2-\mathrm{mm}$ steel wire (70\%), barbed wire $(16 \%), 3-\mathrm{mm}$ steel wire $(6 \%$; all of which are found in the Conservancy fence line), copper wire ( $7 \%$; corresponding to wire used in telephone lines) and 50-mm cable (1\%; matching wire used on power lines). The 84,396 snares removed correspond to c. $289 \mathrm{~km}$ of wire.

Five of the eight management units in the Conservancy reported incidents of anti-poaching scouts being caught hunting illegally during 2008 , involving 22 scouts $(12.5 \%$ of the total).

Snaring resulted in the removal of larger species than hunting with dogs $\left(\chi^{2}=1,495, \mathrm{df}=28, \mathrm{P}<0.001\right)$. For example, buffalo (100\%), zebra (98.3\%), wildebeest (97.4\%), impala (97.4\%) and eland Taurotragus oryx (90.1\%) were killed primarily in snares, whereas hyrax Procavia johnstoni (100\%), warthog (93.2\%), bush pig Potamochoerus porcus (84.8\%) and baboons Papio ursinus (78.6\%) were killed primarily with dogs. Illegal hunting with snares resulted in significant wastage of carcasses. Of the 2,398 animals recorded killed in snares from August 2005 to July 2009, $58.8 \%$ were found rotten or scavenged, $27.3 \%$ were recovered by scouts and $13.9 \%$ were extracted by illegal hunters. A significant number of additional animals were probably extracted by illegal hunters without being detected by scouts. Snaring resulted in the removal of a significant number of female animals (Table 1). Animals were found captured at $41.2 \%$ of snare lines when the snares were located by scouts (mean 1.69 \pm SE 1.54 animals per snare line, range $0-18$ ). The capture rate for illegal hunters using snares was lower than that for other forms of illegal hunting ( $18.6 \%$ vs $21.1 \%$ of incidents involving hunting with dogs and $54.5 \%$ of illegal 
TABLE 1 Animals recorded lost to illegal hunting in Savé Valley Conservancy from August 2001 to July 2009.

\begin{tabular}{llll}
\hline Species & Total killed & Proportion female & Proportion adult \\
\hline Impala Aepyceros melampus & 2,606 & 0.62 & 0.74 \\
Warthog Phacochoerus aethiopicus & 1,018 & 0.44 & 0.89 \\
Kudu Tragelaphus strepsiceros & 788 & 0.75 & 0.75 \\
Wildebeest Connochaetes taurinus & 266 & 0.56 & 0.75 \\
Zebra Equus quagga & 306 & 0.63 & 0.81 \\
Eland Taurotragus oryx & 190 & 0.83 & 0.3 \\
Waterbuck Kobus ellipsiprymnus & 122 & 0.77 & 0.77 \\
Bush pig Potamochoerus larvatus & 85 & 0.4 & 1 \\
Bushbuck Tragelaphus scriptus & 64 & 0.66 & 0.75 \\
Buffalo Syncerus caffer & 43 & 0.54 & 0.71 \\
Black rhino Diceros bicornis & 29 & 0.69 & 0.84 \\
Wild dog Lycaon pictus & 27 & 0.2 & 0.73 \\
Giraffe Giraffa camelopardalis & 21 & 0.34 & 0.2 \\
Sable Hippotragus niger & 20 & 0.5 & 0.66 \\
Elephant Loxodonta africana & 12 & $?$ & $?$ \\
Lion Panthera leo & 7 & $?$ & $?$ \\
Leopard Panthera pardus & 5 & $?$ \\
Cheetah Acinonyx jubatus & 2 & $?$ \\
White rhino Ceratotherium simum & 2 & $?$ \\
Others & 836 & $?$ & $?$ \\
Total & 6,454 & $?$ & $?$
\end{tabular}

fishing; $\left.\chi^{2}=83.75, \mathrm{df}=2, \mathrm{P}<0.001\right)$. Illegal hunters using snares were caught in ambushes at snare lines $(46.0 \%)$ after being seen on patrol (30.1\%) or after a follow-up raid at their homes $(16.8 \%)$. Illegal hunters with dogs were most commonly caught after scouts heard dogs barking (32.6\%), after a follow-up to their homes $(27.2 \%)$ and after their tracks were followed by scouts $(16.3 \%)$.

\section{Anti-poaching effort}

There was marked variation among ranches in Savé Valley Conservancy in investment in anti-poaching, which was reflected in variation in scout-densities, salaries, training levels, and equipment provision (Table 2). Consequently, there was wide variation among ranches in the effectiveness of anti-poaching operations.

\section{Spatial patterns}

Cells in which illegal hunting incidents occurred were closer to the original boundary or nearest resettled areas within Savé Valley Conservancy (Fig. 2; quadratic, $\chi^{2}=$ 154.2, $\mathrm{df}=2, \mathrm{P}<0.001)$, closer to urban areas $(19.0 \pm \mathrm{SE}$ $0.38 \mathrm{~km}$ cf. $19.2 \pm 0.37 \mathrm{~km}$; linear, $\left.\chi^{2}=3.73, \mathrm{df}=1, \mathrm{P}=0.05\right)$ and closer to water sources than those where no incidents were reported $(1.80 \pm 0.10 \mathrm{~km}$ cf. $3.90 \pm \mathrm{SE} 0.15 \mathrm{~km}$; linear, $\left.\chi^{2}=86.3, \mathrm{df}=1, \mathrm{P}=0.05\right)$ and formed a higher percentage of the cells with high (73.3\%) or low (42.6\%) anti-poaching effort than medium effort $\left(40.3 \%\right.$; $\chi^{2}=57.0, \mathrm{~d}=2, \mathrm{P}<$ o.oo1). There was an interaction between anti-poaching effort and distance from the boundary, with low antipoaching effort closest to the boundary, followed by high and then medium effort (low effort: $1.40 \pm$ SE $0.27 \mathrm{~km}$ from the boundary; high: $2.22 \pm$ SE $0.30 \mathrm{~km}$; medium: $4.77 \pm \mathrm{SE}$ $\left.0.37 \mathrm{~km} ; \chi^{2}=61.0, \mathrm{df}=4, \mathrm{P}<0.001\right)$. This implies that cells closer to the boundary had more illegal hunting incidents even taking into account variation in antipoaching effort.

There were more illegal hunting incidents per $\mathrm{km}^{2}$ on ranches in the south (adjacent to resettled areas) than in the unsettled north of the Conservancy $\left(4.63 \pm \mathrm{SE} 1.53 \mathrm{~km}^{-2}\right.$ year ${ }^{-1}$ cf. $1.46 \pm$ SE $0.32 \mathrm{~km}^{-2}$ year ${ }^{-1}$ ), more animals killed per $\mathrm{km}^{2}$ (1.78 \pm SE 0.68 year $^{-1} \mathrm{cf} .0 .98 \pm$ SE $0.21 \mathrm{~km}^{-2}$ ) and more snares removed per $\mathrm{km}^{2}\left(19.7 \pm \mathrm{SE} 0.34 \mathrm{~km}^{-2}\right.$ year ${ }^{-1} \mathrm{cf} .11 .3 \pm$ SE $0.43 \mathrm{~km}^{-2} ; \chi^{2}=9.40, \mathrm{df}=3, \mathrm{P}=0.024$; JMPIN, 2000). Areas worst affected by illegal hunting were ranches settled during land reform, those adjacent to resettled ranches and those close to urban centres outside the Conservancy (Fig. 1). Of the 59 rhinoceroses poached in the Conservancy from 2000 to September 2010, 49 were killed on or close to resettled ranches.

\section{Temporal patterns}

There was a peak in illegal hunting during the late dry season and an inverse correlation between rainfall and illegal hunting $(\mathrm{df}=1, F$ ratio $=11.27, \mathrm{P}=0.002)$. The mean number of illegal hunting incidents (adjusted for variation in anti-poaching effort) peaked in the months of October (mean $168 \pm$ SE 10.5 incidents; $48.3 \pm$ SE $34 \mathrm{~mm}$ of rainfall), 
TABLE 2 Anti-poaching effort and efficacy on ranches within the north and south of Savé Valley Conservancy.

\begin{tabular}{|c|c|c|c|c|c|c|c|c|c|c|c|c|c|}
\hline Ranch & Size $\left(\mathrm{km}^{2}\right)$ & $\begin{array}{l}\text { Monthly } \\
\text { expenditure on } \\
\text { anti-poaching } \\
\mathrm{km}^{-2} \text { (USD) }\end{array}$ & $\begin{array}{l}\text { No. of } \\
\text { scouts }^{1}\end{array}$ & $\begin{array}{l}\text { Mean scout } \\
\text { days } \\
\text { month }^{-1} \mathrm{~km}^{-2} 2\end{array}$ & $\begin{array}{l}\text { Scouts } \\
\mathrm{km}^{-2}\end{array}$ & $\begin{array}{l}\text { Scout } \\
\text { salary } \\
\text { in } \mathrm{USD}^{3}\end{array}$ & $\begin{array}{l}\text { Scouts given } \\
\text { rations? }\end{array}$ & $\begin{array}{l}\text { Scouts } \\
\text { trained? }\end{array}$ & $\begin{array}{l}\% \text { time } \\
\text { scouts } \\
\text { supervised }^{4}\end{array}$ & $\begin{array}{l}\text { Radios } \\
\text { scout }^{-1}\end{array}$ & $\begin{array}{l}\text { Weapons } \\
\text { scout }^{-15}\end{array}$ & $\begin{array}{l}\text { Handcuffs } \\
\text { scout }^{-1}\end{array}$ & $\begin{array}{l}\% \text { incidents } \\
\text { where } \geq 1 \text { hunter } \\
\text { caught }\end{array}$ \\
\hline \multicolumn{14}{|l|}{ North } \\
\hline Bedford & 123.5 & 8.81 & 12 & 2.10 & 0.10 & 22.5 & Yes & No & 50 & 0.33 & 0.33 & 1 & 30 \\
\hline Chishakwe & 95.7 & 9.40 & 8 & 1.61 & 0.08 & 29 & Yes & Yes & 2 & 0.33 & 0.38 & 0.33 & 18 \\
\hline Gunundwe & 113.7 & 0.75 & 7 & 0.85 & 0.04 & 5 & Yes & No & 2 & 0.4 & 0.4 & 0.4 & 11 \\
\hline Matendere & 135.2 & 2.96 & 7 & 1.32 & 0.06 & 15 & No & No & 0 & 0.33 & 0.33 & 0.88 & 13 \\
\hline Mokore block & 196.1 & 2.55 & 12 & 3.52 & 0.03 & 10 & Yes & Yes & 100 & 0.29 & 0.57 & 0.29 & 18 \\
\hline Msaize/Mapari & 394.6 & 1.99 & 28 & 1.58 & 0.06 & 5 & Yes & No & 75 & 0.18 & 0.05 & 0.54 & 12 \\
\hline Sango & 573 & 2.18 & 20 & 0.85 & 0.05 & 15 & Yes & No & 100 & 0.33 & 0.26 & 0.33 & 42 \\
\hline North total/average & $1,631.8$ & 3.1 & 82 & 1.53 & 0.06 & 12.7 & 0.92 & 0.18 & 69.2 & 0.29 & 0.28 & 0.48 & 22 \\
\hline \multicolumn{14}{|c|}{ South } \\
\hline Hammond block & 152.5 & 9.84 & 16 & 0.94 & 0.13 & 10 & Yes & Yes & 100 & 0.5 & 0.05 & 0.25 & 7.3 \\
\hline Hippo Haven & 25 & 2.55 & 2 & 3.52 & 0.08 & 10 & Yes & Yes & 100 & 0.29 & 0.57 & 0.29 & 3.1 \\
\hline Humani block & 216.9 & 8.81 & 21 & 2.1 & 0.1 & 22.5 & Yes & No & 50 & 0.33 & 0.33 & 1 & 28 \\
\hline Impala & 75.3 & 7.97 & 14 & 4.82 & 0.19 & 6 & Yes & No & 7 & 0.5 & 0.5 & 0.5 & 48 \\
\hline Senuko block & 306.3 & 9.79 & 25 & 1.35 & 0.08 & 30 & Yes & Yes & 100 & 0.24 & 0.24 & 0.5 & 17 \\
\hline Masapas & 154.3 & 0.23 & 6 & 0.78 & 0.04 & 6 & No & No & 0 & 0 & 0 & 0.5 & 28 \\
\hline South total/average & 930.3 & 7.82 & 84 & 1.72 & 0.09 & 18.4 & 0.83 & 0.52 & 64.42 & 0.28 & 0.22 & 0.57 & 22 \\
\hline
\end{tabular}

${ }^{1}$ Mean number of scouts employed from January 2007 to May 2008

${ }^{2}$ Mean scout days per month during January 2007 to May 2008, per $\mathrm{km}^{2}$

${ }^{3}$ Calculated at the parallel market exchange rates. To contextualize these data it is important to note that at the time of the study salaries for most professions in both the private and the public sector in Zimbabwe were extremely low. Following the legalization of the use of foreign currency, salaries of scouts have increased to USD $70-100$ month $^{-1}$ )

${ }^{4}$ The percentage of working time that scouts are accompanied by management

${ }^{5}$ Shotguns issued to scouts for the purposes of self-defence from illegal hunters 


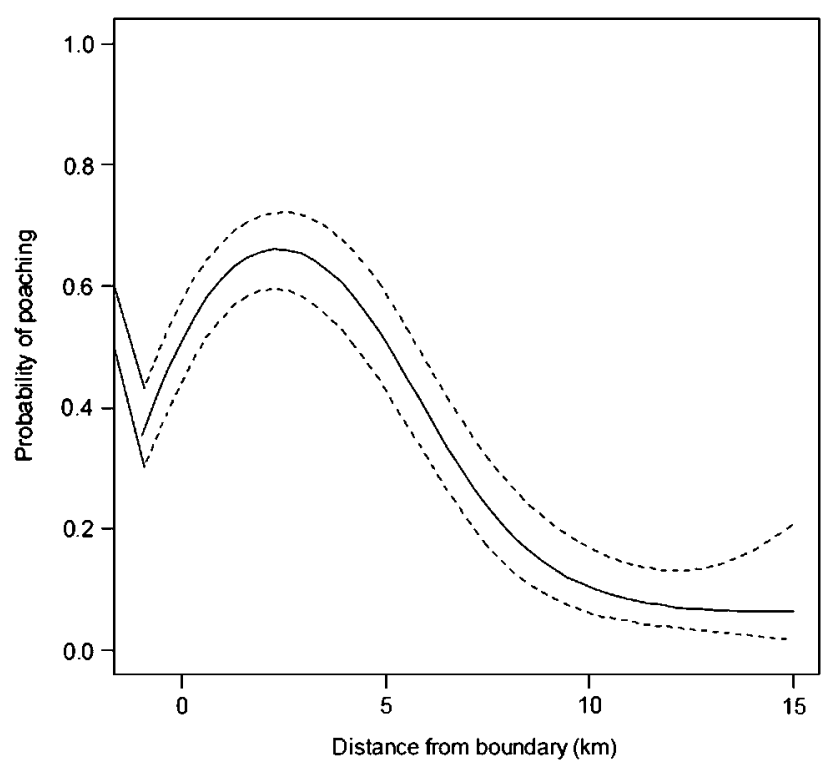

FIG. 2 Relationship between the probability of illegal hunting incidents occurring and distance from the boundary or nearest resettled area within Savé Valley Conservancy (Fig. 1; with 95\% confidence intervals).

August (149 \pm SE 7.95; $1.4 \pm$ SE $1.0 \mathrm{~mm}$ ) and September $(147 \pm \mathrm{SE} 19.6 ; 3.8 \pm \mathrm{SE} 3.4 \mathrm{~mm})$ and was lowest in January ( $93 \pm$ SE 12.5; $213 \pm$ SE $50 \mathrm{~mm}$ ), February (93 \pm SE 16.0; $61.3 \pm \mathrm{SE} 19 \mathrm{~mm})$ and December (100 \pm SE 17.8; $63.7 \pm \mathrm{SE}$ $31 \mathrm{~mm}$ ). The prevalence of different types of illegal hunting varied among seasons $\left(\chi^{2}=18.9, \mathrm{df}=6, \mathrm{P}=0.004\right)$. Snaring, hunting with dogs and fishing, respectively, comprised the following proportion of total incidences in each season: cool dry: $0.65,0.32$ and 0.03 ; hot dry: $0.64,0.32$ and 0.04 ; hot wet: $0.63,0.29$ and 0.08 . The use of dogs peaked during the first quarter and full moon stages of the moon phase ( 28.5 and $26.0 \%$, respectively, of incidents involving dogs) and dropped during the new moon $\left(21 \% ; \chi^{2}=34.9, \mathrm{df}=11\right.$, $\mathrm{P}=0.003)$.

In June 2007 price controls were imposed on foodstuffs in Zimbabwe, which reduced the availability of groceries (including meat) in stores throughout the country. The mean weekly number of incidences of illegal hunting was higher during June-December 2008 (35.4 \pm SE 1.61) and June-December 2007 (30.2 \pm SE 1.94) than during the same period in 2006 (25.4 \pm SE 2.54).

\section{Ecological impacts of illegal bushmeat hunting}

Recorded losses corresponded to the removal of $24.6 \mathrm{~kg}$ mammalian biomass per $\mathrm{km}^{2}$ during 2007. Wildlife populations have been largely eradicated on the settled properties (Fig. 3). Given losses $250 \%$ worse than recorded in the south and $100 \%$ worse in the north, the numbers of most species are projected to decline in the south during the next
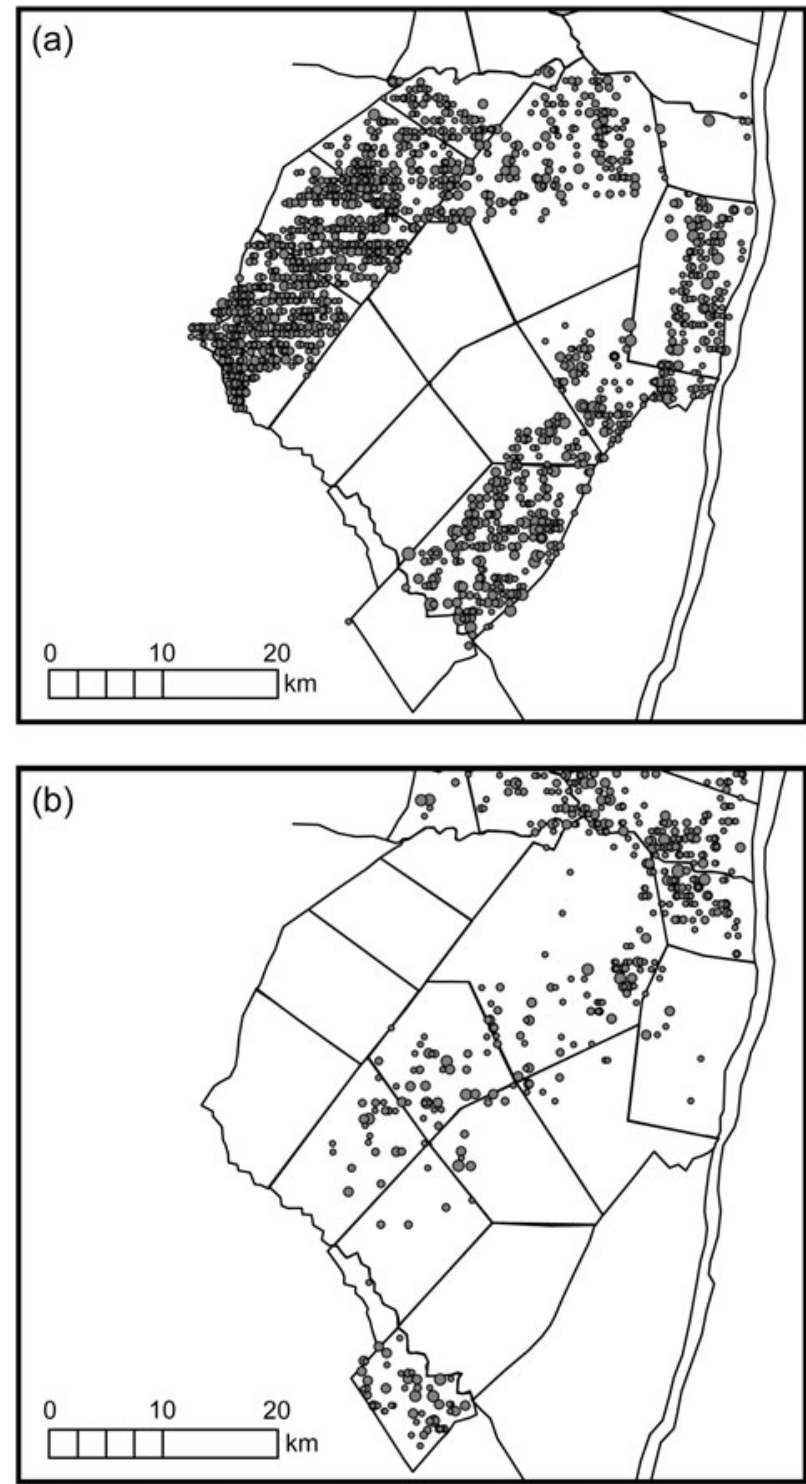

Fig. 3 Distribution of (a) settlers' cattle and (b) impala Aepyceros melampus in the southern half of Savé Valley Conservancy (from 2004 aerial census data; Joubert \& Joubert, 2008). The sizes of the circles are proportional to the herd sizes sighted.

15 years (Fig. 4a), whereas in the north the numbers of most species are projected to increase (Fig. $4 \mathrm{~b}$ ). When the models were run assuming recorded losses to illegal hunting most species in the north and south were no longer projected to decline. However, warthog in the north and south and sable in the south were projected to decline to zero. Impala populations are projected to increase significantly in both the south and north of the Conservancy for both estimated poaching levels and observed poaching effort. Aerial census data from 2008 suggests that the reality is worse than the predictions for several species in the south (Fig. 5a), indicating that illegal hunting losses may be even higher than the managers' estimates used to construct the models. Wildlife populations in the north are generally stable (Fig. 

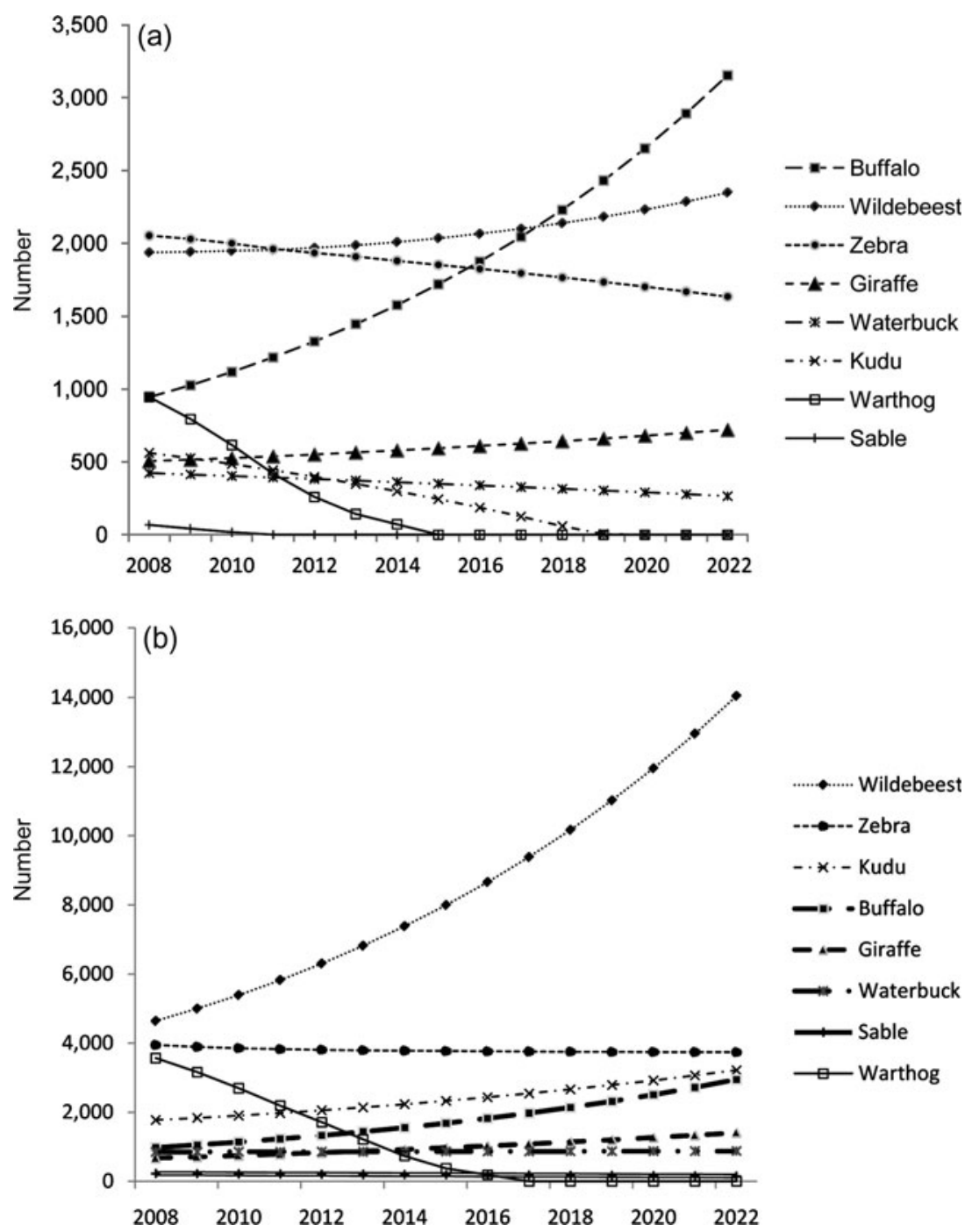

Fig. 4 Projected population trends arising from the combined effects of legal and illegal hunting in the (a) south and (b) north of Savé Valley Conservancy (Fig. 1).

5b). Impala populations declined by 0.2 and $38.2 \%$ during 2007-2008 in the north and south of the Conservancy, respectively.

\section{Financial impacts}

From August 2005 to July 2009, based on recorded illegal hunting data, financial losses included USD 100,529 of potential meat sales (USD 25,132 year $^{-1}$; Table 3) and USD 572,833 of lost potential income from hunts of rare/highvalue species (USD 143,208 year $^{-1}$; Table 4). If losses to illegal hunting equalled managers' estimates $(161.5 \%$ worse than official statistics), foregone meat sales and hunts of rare/valuable species would impose annual costs of USD 60,435 and USD 348,708, respectively. An additional USD 160,328 year $^{-1}$ was lost through illegal rhinoceros hunting. Quotas of some species should be cut to compensate for losses to illegal hunting. Such quota cuts would result in potential future annual losses of USD 213,998-335,348
(Table 5). Total annual costs (including anti-poaching expenditures of USD 179,472 year $^{-1}$ ) were USD 722,128 or USD $1,141,458$, assuming that losses were $161.5 \%$ worse than reflected by recorded data (except for rhinoceroses that are closely monitored and so loss data are more accurate than for other species).

Illegal hunters' earnings are markedly lower than the costs they impose. Given a price of USD 0.39 for illegal bushmeat (Lindsey et al., 2011) and given that $86.1 \%$ of animals killed by illegal hunters rot or are recovered by the ranches before being retrieved, then annual earnings of illegal hunters from meat sales would amount to USD 2,270. Earnings would be USD 5,938 if one assumes that illegal hunting levels are $161.5 \%$ higher than reflected by illegal hunting data (if all animals killed above those documented in the data are successfully retrieved by hunters). Illegal hunters' earnings thus account for $0.31-0.52 \%$ of the financial losses that they impose (excluding unknown earnings from selling rhinoceros horns). 


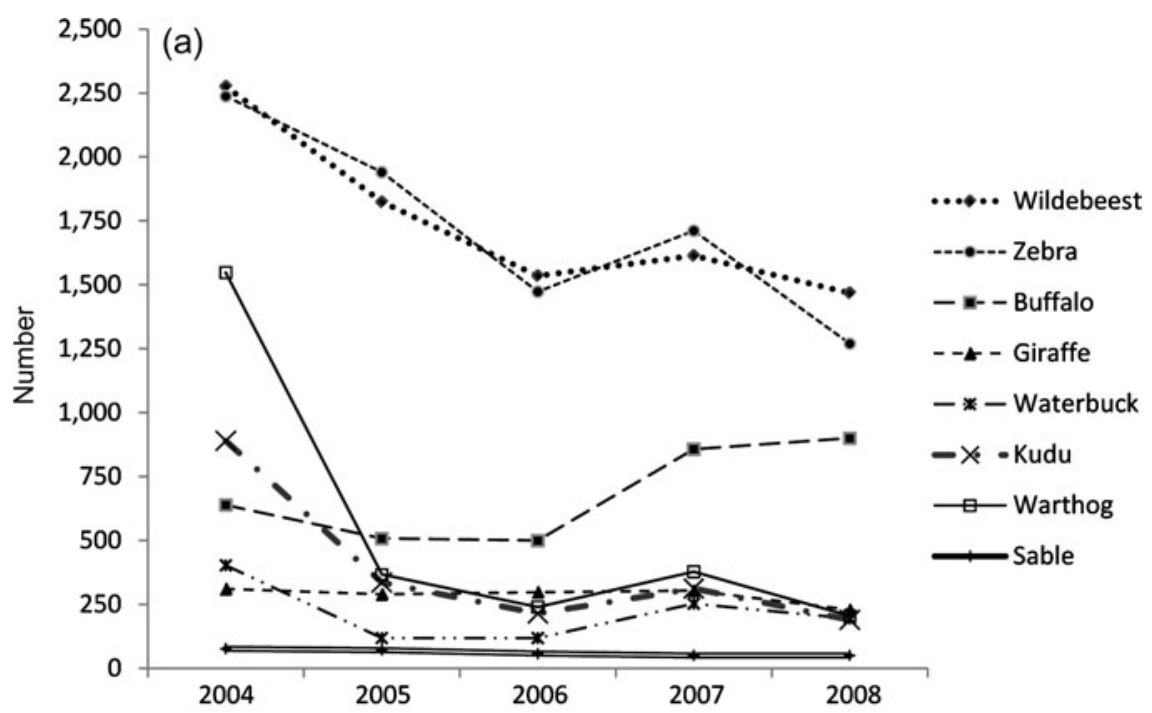

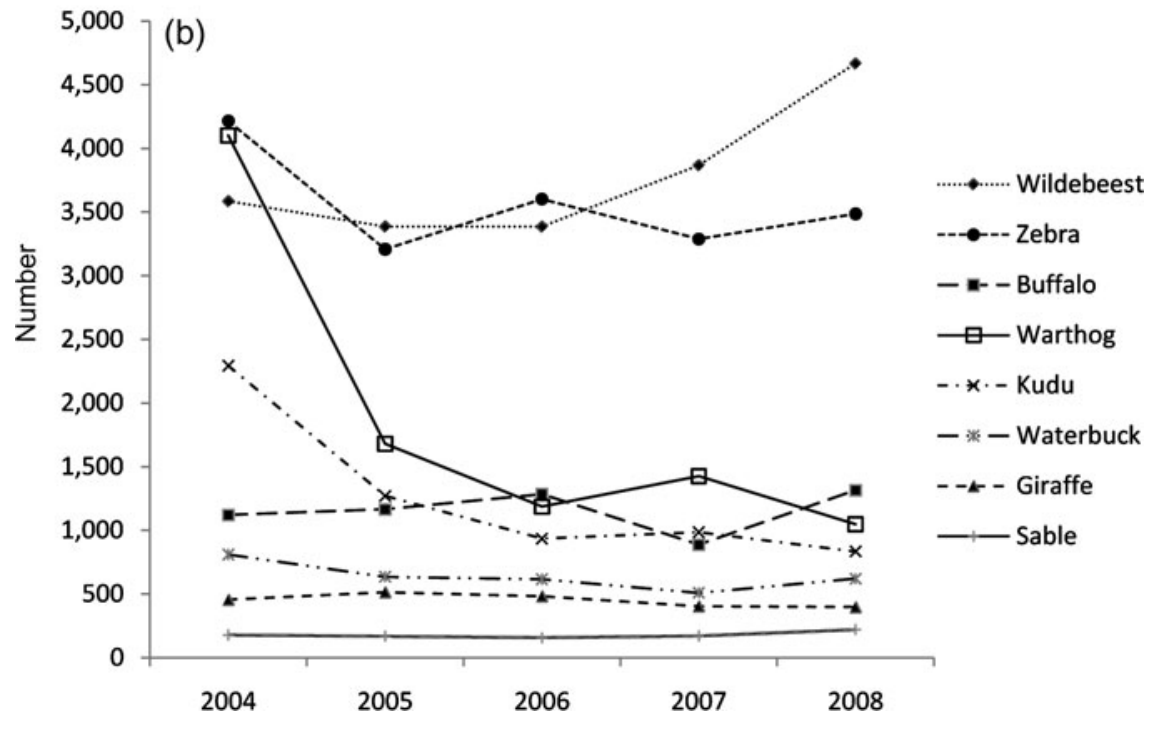

FIG. 5 Observed population trends (2004-2008) for eight large mammal species in (a) the south and (b) the north of Savé Valley Conservancy (Fig. 1).
Illegal hunting in other wildlife areas in the South-East Lowveld

Several other private reserves have been affected by illegal hunting (Tables $6 \& 7$ ). Respondents from Chiredzi River Conservancy, Triangle Estates, Eaglemont Ranch and Savé Valley Conservancy all indicated that large-scale illegal hunting commenced with the onset of settlement during land reform and that wildlife has been virtually eradicated from settled areas. All ranchers whose properties were affected by settlement $(n=8)$ indicated that widespread bush clearing, increased frequency of bush fires, destruction of perimeter fencing and loss of tourism revenues accompanied settlement. On six of the nine settled ranches in the Conservancy, and on the settled portions of Triangle Estates and Eaglemont, tourism has ceased completely. In Chiredzi River Conservancy one landowner of 10 still conducts safari hunting tourism.
Respondents from Malilangwe Trust and Gonarezhou indicated that little illegal hunting occurs. Malilangwe Trust has not been settled and has an effective anti-poaching force (spending USD $23 \mathrm{~km}^{-2}$ month $^{-1}$ vs USD $5.5 \mathrm{~km}^{-2}$ month $^{-1}$ in Savé Valley Conservancy, and employing 0.12 scouts $\mathrm{km}^{-2}$ vs $0.07 \mathrm{~km}^{-2}$ in the Conservancy) and invests c. USD 700,000 year ${ }^{-1}$ on community outreach (expenditure by the Conservancy is undocumented but certainly lower). In Gonarezhou a low incidence of illegal bushmeat hunting was reported. During 2007 and 2008, 88 and 70 animals, respectively, were recorded lost to illegal hunting or 0.03 animals $\mathrm{km}^{-2}$ year ${ }^{-1}$ vs 0.26 animals $\mathrm{km}^{-2}$ year ${ }^{-1}$ in Savé Valley Conservancy.

However, anti-poaching effort in Gonarezhou is lower than in Savé Valley Conservancy, both in terms of scout densities (0.018 km ${ }^{-2} \mathrm{cf} .0 .07 \mathrm{~km}^{-2}$ in the Conservancy) and expenditures on anti-poaching (USD $0.09 \mathrm{~km}^{-2}$ month $^{-1} \mathrm{vs}$ USD $5.5 \mathrm{~km}^{-2}$ month $^{-1}$ in the Conservancy). Partly for this 
TABLE 3 Lost potential revenues (USD) from meat sales because of illegal hunting from August 2005 to July 2009.

\begin{tabular}{|c|c|c|c|c|c|c|c|c|c|c|c|c|}
\hline & $\begin{array}{l}\text { Dressed } \\
\%^{1}\end{array}$ & $\begin{array}{l}\text { Average } \\
\text { mass }^{2}\end{array}$ & $\begin{array}{l}2005 \\
\text { No. } \\
\text { killed }\end{array}$ & Value $^{3}$ & $\begin{array}{l}2006 \\
\text { No. } \\
\text { killed }\end{array}$ & Value $^{3}$ & $\begin{array}{l}2007 \\
\text { No. } \\
\text { killed }\end{array}$ & Value $^{3}$ & $\begin{array}{l}2008 \\
\text { No. } \\
\text { killed }\end{array}$ & Value $^{3}$ & $\begin{array}{l}2009 \\
\text { No. } \\
\text { killed }\end{array}$ & Value $^{3}$ \\
\hline Buffalo & 0.5 & 495 & 13 & 1,931 & 3 & 446 & 3 & 446 & 12 & 1,782 & 5 & 743 \\
\hline Bushbuck & 0.55 & 29 & 6 & 57 & 13 & 124 & 6 & 57 & 5 & 48 & 2 & 19 \\
\hline Bush pig & 0.61 & 54.5 & 16 & 319 & 14 & 279 & 13 & 259 & 2 & 40 & 4 & 80 \\
\hline Duiker Sylvicapra grimmia & 0.61 & 11.4 & 1 & 4 & 1 & 4 & 5 & 21 & 0 & 0 & 1 & 4 \\
\hline Eland & 0.51 & 550 & 4 & 673 & 9 & 1,515 & 19 & 3,198 & 28 & 4,712 & 10 & 1,683 \\
\hline Elephant & 0.61 & 1,725 & 0 & 0 & 1 & 631 & 1 & 631 & 0 & 0 & 0 & 0 \\
\hline Giraffe & 0.58 & 828 & 1 & 288 & 2 & 576 & 5 & 1,441 & 1 & 288 & 1 & 288 \\
\hline Grysbok Raphicerus sharpei & 0.55 & 7.6 & 0 & 0 & 1 & 3 & 3 & 8 & 1 & 3 & 0 & 0 \\
\hline Hartebeest Alcelaphus buselaphus & 0.55 & 160 & 0 & 0 & 1 & 37 & & 0 & 0 & 0 & 0 & 0 \\
\hline Hyrax Procavia johnstoni & 0.61 & 4.5 & 6 & 10 & 2 & 3 & 56 & 92 & 47 & 77 & 24 & 40 \\
\hline Impala & 0.58 & 45 & 174 & 2,725 & 218 & 3,414 & 326 & 5,105 & 499 & 7,814 & 210 & 3,289 \\
\hline Klipspringer Oreotragus oreotragus & 0.55 & 10.3 & 3 & 10 & 5 & 17 & 2 & 7 & 3 & 10 & 0 & 0 \\
\hline Kudu & 0.57 & 136.4 & 61 & 2,846 & 46 & 2,146 & 50 & 2,332 & 45 & 2,099 & 35 & 1,633 \\
\hline Nyala Tragelaphus angasii & 0.55 & 72 & 0 & 0 & 0 & 0 & 3 & 71 & 0.00 & 0 & 1.00 & 24 \\
\hline Sable & 0.55 & 180 & 3 & 178 & 1 & 59 & 0 & 0 & 1 & 69.3 & 5 & 347 \\
\hline Warthog & 0.54 & 30 & 190 & 1,847 & 125 & 1,215 & 175 & 1,701 & 59 & 1,147 & 28 & 544 \\
\hline Waterbuck & 0.55 & 180 & 13 & 772 & 12 & 713 & 18 & 1,069 & 20 & 1,188 & 12 & 713 \\
\hline Wildebeest & 0.56 & 180 & 17 & 1,028 & 29 & 1,754 & 58 & 3,508 & 46 & 2782 & 27 & 1,633 \\
\hline Zebra & 0.55 & 320 & 31 & 3,274 & 19 & 2,006 & 27 & 2,851 & 54 & 5702 & 76 & 8,026 \\
\hline Total & & & & 15,962 & & 14,942 & & 22,798 & & 27,763 & & 19,064 \\
\hline
\end{tabular}

${ }^{1}$ Bothma (2002)

${ }^{2}$ Of an individual within the population (Bothma, 2002)

${ }^{3}$ Based on a meat price of USD $0.60 \mathrm{~kg}^{-1}$

reason, large ungulates (except elephants Loxodonta africana) occur at densities 1.06-25.8 times lower in Gonarezhou than in the Conservancy (Dunham et al., 2007; Joubert \& Joubert, 2008).

\section{Discussion}

A questionnaire survey formed a central role in collecting data for this study and, consequently, the reliability of the data presented is dependent on the fidelity of information provided. Land owners and managers were willing to participate in our study and the information they provided is congruent with the impressions of three of the authors who have worked within Savé Valley Conservancy for several years prior to and during this study.

In the South-East Lowveld the bushmeat trade has emerged as a severe threat to wildlife populations and the viability of wildlife-based land uses following a volatile land reform process and dramatic changes in land tenure. Prior to the land reform programme in 2000 illegal hunting in the area was less prevalent, suggesting that the bushmeat trade may represent an incipient conservation threat that manifests itself more seriously under conditions of political and economic instability. Similarly, illegal bushmeat hunting emerged as a serious problem in parks in Mozambique and the Democratic Republic of

TABLE 4 Lost potential trophy hunting income (USD) from high-value species killed by illegal hunters.

\begin{tabular}{|c|c|c|c|c|c|c|c|c|c|c|c|c|c|}
\hline \multirow[b]{2}{*}{ Species } & \multirow[b]{2}{*}{$\begin{array}{l}\text { Trophy } \\
\text { fee }\end{array}$} & \multirow[b]{2}{*}{$\begin{array}{l}\text { Daily } \\
\text { rate }\end{array}$} & \multirow[b]{2}{*}{$\begin{array}{l}\text { Min. hunt } \\
\text { length }\end{array}$} & \multicolumn{2}{|l|}{2005} & \multicolumn{2}{|l|}{2006} & \multicolumn{2}{|l|}{2007} & \multicolumn{2}{|l|}{2008} & \multicolumn{2}{|l|}{2009} \\
\hline & & & & $\begin{array}{l}\text { No. } \\
\text { killed }\end{array}$ & $\begin{array}{l}\text { Lost } \\
\text { potential } \\
\text { income }\end{array}$ & $\begin{array}{l}\text { No. } \\
\text { killed }\end{array}$ & $\begin{array}{l}\text { Lost } \\
\text { potential } \\
\text { income }\end{array}$ & $\begin{array}{l}\text { No. } \\
\text { killed }\end{array}$ & $\begin{array}{l}\text { Lost } \\
\text { potential } \\
\text { income }\end{array}$ & $\begin{array}{l}\text { No. } \\
\text { killed }\end{array}$ & $\begin{array}{l}\text { Lost } \\
\text { potential } \\
\text { income }\end{array}$ & $\begin{array}{l}\text { No. } \\
\text { killed }\end{array}$ & $\begin{array}{l}\text { Lost } \\
\text { potential } \\
\text { income }\end{array}$ \\
\hline Cheetah & 2,700 & 850 & 14 & 0 & 0 & 0 & 0 & 0 & 0 & 1 & 14,600 & 0 & 0 \\
\hline Leopard & 3,500 & 883 & 14 & 0 & 0 & 0 & 0 & 4 & 63,448 & 0 & 0 & 0 & 0 \\
\hline Lion & 7,450 & 1,672 & 20 & 5 & 204,450 & 1 & 40,890 & 0 & 0 & 1 & 40,890 & 0 & 0 \\
\hline Sable & 3,528 & 1,055 & 12 & 3 & 48,564 & 1 & 16,188 & 0 & 0 & 1 & 16,188 & 5 & 86,215 \\
\hline Zebra & $200^{*}$ & & & 31 & 6,200 & 19 & 3,800 & 27 & 5,400 & 54 & 10,800 & 76 & 15,200 \\
\hline Total & & & & & 259,214 & & 60,878 & & 68,848 & & 82,478 & & 101,415 \\
\hline
\end{tabular}

*Average skin value (obtained from a skin dealer operating in Savé Valley Conservancy) 
TABLE 5 Quota reductions necessary to compensate for losses because of poaching in Savé Valley Conservancy (relative to 2007 quotas, assuming that levels of poaching are equal to, or $161.5 \%$ worse than recorded levels).

\begin{tabular}{|c|c|c|c|c|c|c|c|}
\hline & \multirow[b]{2}{*}{$\begin{array}{l}\text { USD } \\
\text { trophy fee }\end{array}$} & \multicolumn{3}{|c|}{$\begin{array}{l}\text { Assuming recorded losses of } \\
\text { animals to illegal hunting }\end{array}$} & \multicolumn{3}{|c|}{$\begin{array}{l}\text { Assuming losses of animals } \\
\text { to illegal hunting } 161.5 \% \text { worse than recorded data }\end{array}$} \\
\hline & & South, n (\%) & North, n (\%) & $\begin{array}{l}\text { Lost potential } \\
\text { income (USD) }\end{array}$ & South, n (\%) & North, n (\%) & $\begin{array}{l}\text { Lost potential } \\
\text { income (USD) }\end{array}$ \\
\hline$\overline{\text { Eland }^{2}}$ & 1,450 & $22(100)$ & 0 & 36,256 & $22(100)$ & 0 & 36,256 \\
\hline Kudu & 1,044 & 0 & 0 & 0 & $9(49)$ & 0 & 10,168 \\
\hline Sable ${ }^{3}$ & 3,528 & $3(100)$ & 0 & 48,797 & $3(100)$ & 0 & 48,797 \\
\hline Warthog & 497 & $4(12)$ & 0 & 2,096 & 37 (100) & $61(100)$ & 51,358 \\
\hline Wildebeest & 761 & $8(14)$ & 0 & 6,748 & $59(100)$ & 0 & 49,767 \\
\hline Zebra & 840 & $54(44)$ & $73(35)$ & 120,091 & $66(54)$ & $81(39)$ & 139,003 \\
\hline Total & & & & 213,988 & & & 335,348 \\
\hline
\end{tabular}

${ }^{1}$ Based on mean male body mass, assuming an average dressing \% of 0.55 and a meat price of USD $0.60 \mathrm{~kg}^{-1}$

${ }^{2}$ Although we were unable to model eland because of missing life-history parameters, the population declined by $61 \%$ during $2007-2008$ in the south of the Conservancy and so hunting is assumed to be unsustainable there (in the north, the eland population increased by $3.9 \%$ and so hunting is assumed to be sustainable)

${ }^{3}$ Sable (unlike the other species presented) are flagship trophy species that are used to sell hunting packages and so the loss of sable results in the loss of the trophy fee, in addition to the average daily rate for sable hunts (USD 1,055) multiplied by the mean length of sable hunts (12 days).

Congo during periods of civil war (Cumming, 2004; de Merode \& Cowlishaw, 2006).

\section{Impacts on wildlife}

Wildlife has been virtually eradicated across large areas of the South-East Lowveld settled during land reform and is declining on adjacent lands. The declines in wildlife populations in the south of Savé Valley Conservancy, for example, severely threaten the viability of wildlife-based land use in the area. Because of excessive losses to illegal

TABLE 6 Estimated percent changes in wildlife populations from before the onset of settlement associated with land reform to the present on three private wildlife areas in south-east Zimbabwe.

\begin{tabular}{|c|c|c|c|}
\hline & $\begin{array}{l}\text { Chiredzi River } \\
\text { Conservancy }\end{array}$ & $\begin{array}{l}\text { Triangle } \\
\text { Estates }\end{array}$ & $\begin{array}{l}\text { Eaglemont } \\
\text { Ranch }\end{array}$ \\
\hline Buffalo & -50 & -95 & 0 \\
\hline Bushbuck & -60 & -95 & $\geq 50$ \\
\hline Bush pig & $?$ & -95 & $?$ \\
\hline Eland & -50 & -95 & $\geq 50$ \\
\hline Elephant & 40 & $?$ & $?$ \\
\hline Giraffe & -40 & -10 & $\geq 50$ \\
\hline Hartebeest & $?$ & -95 & $?$ \\
\hline $\begin{array}{l}\text { Hippopotamus } \\
\text { Hippopotam }\end{array}$ & 20 & -66 & $?$ \\
\hline Impala & -75 & -95 & $\geq 50$ \\
\hline Klipspringer & -60 & -95 & $\geq 50$ \\
\hline Kudu & -80 & -95 & $\geq 50$ \\
\hline Leopard & -30 & -95 & $\geq 50$ \\
\hline Sable & -95 & -99 & $\geq 50$ \\
\hline Warthog & -90 & -10 & $\geq 50$ \\
\hline Waterbuck & -80 & -95 & $\geq 50$ \\
\hline Wild dog & -100 & -100 & $\geq 50$ \\
\hline Wildebeest & -40 & -95 & $\geq 50$ \\
\hline Zebra & -40 & -95 & $\geq 50$ \\
\hline
\end{tabular}

hunting, safari hunting quotas are too high and probably contribute to wildlife population declines. Illegal bushmeat hunting probably occurs in a significant proportion of the $\mathrm{c}$. 1.4 million $\mathrm{km}^{2}$ used for safari hunting in sub-Saharan Africa (Lindsey et al., 2007). Our results emphasize the importance of monitoring bushmeat hunting to ensure the sustainability of safari hunting quotas. However, our results also demonstrate the importance of safari hunting for creating incentives and funding for anti-poaching. Due to the political instability, ecotourism operations in the Conservancy have largely ceased to function in recent years, whereas safari hunting has been little affected (Lindsey et al. 2009). Consequently, safari hunting generates the only source of income with which to pay for the $\mathrm{c}$. USD 180,000 spent on anti-poaching, and without such revenue the impacts of illegal hunting would probably have been much greater.

Illegal hunting results in the destruction of wildlife for the capture of $<1 \%$ of the value of the animals killed. Some threatened species have been particularly affected by illegal hunting. Wild dogs, for example, have been eradicated, by snaring, from Chiredzi River Conservancy and Triangle Estates and reduced from three packs to one in the south of the Conservancy (Pole, 1999). Similarly, populations of black rhinoceros are declining in the Conservancy following the loss of 29 animals from a population of c. 120 individuals within 4 years.

Snaring is the most common form of illegal hunting in the South-East Lowveld and is particularly undesirable from conservation and animal welfare perspectives. Snaring is difficult to control and if unchecked can cause rapid extirpation of wildlife populations (Lewis \& Phiri, 1998). Snaring is indiscriminate (most mammals $>3-5 \mathrm{~kg}$ are affected, including some not considered food items, e.g. wild dogs and hyaenas Crocuta crocuta). All age and sex classes are 
TABLE 7 Area remaining under wildlife management, percentage of area lost during land reform, percentage of game fence lost, number of scouts employed and their density, and number of shares removed following settlement of six private wildlife reserves in south-east Zimbabwe.

\begin{tabular}{|c|c|c|c|c|c|c|c|}
\hline Ranch & $\begin{array}{l}\text { Managed } \\
\text { area } \\
\text { remaining } \\
\left(\mathrm{km}^{2}\right)\end{array}$ & $\begin{array}{l}\% \text { land area } \\
\text { lost to settlement } \\
\text { during land } \\
\text { reform }\left(\mathrm{km}^{2}\right)\end{array}$ & $\begin{array}{l}\text { Game fence } \\
\text { removed by } \\
\text { settlers }(\%)\end{array}$ & $\begin{array}{l}\text { Scouts } \\
\text { employed }\end{array}$ & $\begin{array}{l}\text { Scouts } \\
\mathrm{km}^{-2}\end{array}$ & $\begin{array}{l}\text { Snares } \\
\text { removed } \mathrm{km}^{-2} \\
\text { year }{ }^{-1} \text { by } \\
\text { scouts }\end{array}$ & $\begin{array}{l}\text { Snares } \\
\text { removed adjusted } \\
\text { for anti-poaching } \\
\text { effort }{ }^{1}\end{array}$ \\
\hline Chiredzi River Conservancy & 210 & $80(864)$ & 100 & 20 & 0.10 & 28.2 & 20.8 \\
\hline Triangle & 500 & $70(350)$ & 100 & 25 & 0.05 & 11.7 & 16.5 \\
\hline Eaglemont & 100 & $41(70)$ & 100 & $?$ & $?$ & 104.5 & $?$ \\
\hline Savé Valley Conservancy & 2,571 & $33(1,043)$ & 22.9 & 176 & 0.07 & 4.1 & 4.2 \\
\hline Malilangwe & 500 & 0 & 0 & 60 & 0.12 & 0.25 & 0.15 \\
\hline Gonarezhou & 5,050 & $0.8(40)$ & $\mathrm{N} / \mathrm{A}^{2}$ & 90 & 0.02 & $?$ & $?$ \\
\hline
\end{tabular}

${ }^{\text {a1 }}$ Adjustment made on deviation from the mean density of scouts for the five areas sampled

${ }^{2}$ Little of the Gonarezhou veterinary fence was remaining even prior to settlement because of lack of maintenance (C. Stockil, pers. comm.)

affected and impacts on populations are greater than those resulting from selective legal hunting. Snaring is wasteful and in the Conservancy at least 1,410 animal carcasses rotted in snares or were scavenged during 2005-2009.

\section{Insights into the prevention and management of illegal hunting}

Focusing anti-poaching efforts Illegal hunting peaks in Savé Valley Conservancy during the late dry season, a phenomenon likely to be replicated elsewhere. During the rainy season high river levels may reduce access for bushmeat hunters (as occurs in the Conservancy), hunters are likely to be occupied with agriculture, and the dispersal of wildlife probably makes hunting more difficult. Hunting with dogs peaks at night during the early and full moon. In keeping with findings from Tsavo National Park (Wato et al., 2006), hunting was more frequent near water sources and close to human settlements. In the Conservancy anti-poaching is poorly focused, with lower effort in areas with higher threats from illegal hunting. Appropriate focusing of scouts in line with predictable temporal and spatial patterns in illegal bushmeat hunting would increase the efficacy of anti-poaching in the Conservancy and elsewhere.

Land use planning and future land reform efforts Land reform in the South-East Lowveld resulted in the settlement of communities on game ranches, who were then encouraged to practise rain-fed agriculture on unsuitable land. Private land was converted to communal land with open access to natural resources, which were subsequently degraded rapidly. Land reform is high on the political agenda in both South Africa and Namibia and planning is required to ensure that the mistakes in Zimbabwe are not replicated. In South Africa and Namibia dialogue among conservationists, landowners and government is required to facilitate the integration of communities in game ranching areas into wildlife-based land uses during land reform. Skills transfer is required to enable new entrants in the game ranching industry to develop successful tourism enterprises. The strategy employed by the Makuleke community in South Africa represents a model that could potentially be employed elsewhere. Following a successful land claim involving part of Kruger National Park, the community allowed South African National Parks and tourism operators to co-manage their land in return for dividends from tourism activities (Grossman \& Holden, 2009). The co-management arrangement prevented the problems experienced during land reform in Savé Valley Conservancy and ensured that the process did not compromise conservation objectives (Grossman \& Holden, 2009). Future land reform efforts should ensure legitimate transfer of title deeds to the intended recipients to provide incentives for long-term management of natural resources.

Implications for land-use planning and reserve design In Savé Valley Conservancy illegal hunting is most frequent near the edges of the wildlife area and a 'safe zone' exists where incidents are rare. Similarly, in Central Africa, halos of defaunation exist around villages (Wilkie et al., 1998). These trends illustrate the importance of minimizing the perimeter to area ratio when designing protected areas. Equally, when planning land reform, retaining a degree of separation between land used for wildlife and that used for human settlement is important. Such planning would also minimize the human-wildlife conflict that severely affects resettled communities in the Conservancy (Lindsey et al., 2009).

The need for care when constructing game fences The prevalence of game fencing in the South-East Lowveld provides illegal hunters with an effectively limitless supply of snare material. Game fences should be constructed of alternative materials, such as kinked mesh fencing, which cannot be used to make snares. This is particularly important when wildlife-based land uses are being 
developed in areas where wire is not readily available. In central Mozambique, for example, most illegal hunting is conducted with costly leg-hold traps, the confiscation of which represents a major hindrance for hunters (Lindsey \& Bento, 2010).

Appropriate leasing structures The lack of anti-poaching on the government-owned property in Savé Valley Conservancy highlights the importance of appropriate lease agreements, with conditions relating to minimum required investments in anti-poaching. The government leased hunting rights on Potential Ranch to a safari operator on a short-term (1-2 years) basis, with no requirement for that company to assist with anti-poaching. Fortunately, since data collection was completed, the lease was obtained by a more responsible operator who invests heavily in antipoaching. Nonetheless, inappropriate, vague and/or unenforced leasing agreements for safari hunting and photographic tourism concessions are widespread in Africa (Lindsey et al., 2007). Similarly, variation in investment in anti-poaching among the ranches in the Conservancy provides insights into the importance of considering security commitments when developing constitutions for multi-owner conservancies. Because of the lack of internal fencing, ranchers with poor security (who lose many animals to poachers) still derive returns from safari hunting because of influxes of wildlife from adjacent properties. Conservancy constitutions should require minimum standards of per capita investment in anti-poaching for landowners to qualify for safari hunting quotas. In cases where some ranches in conservancies face excessive pressure from illegal hunting (as in Savé Valley Conservancy), the establishment of some form of centralized anti-poaching unit to provide assistance to such ranchers may be merited.

The importance of adequate training, equipment and supervision of scouts Inadequate salaries, equipment, training and supervision of scouts significantly undermine the effectiveness of anti-poaching in Savé Valley Conservancy, reduce morale and increase the risk of scouts engaging in illegal hunting. In Ghana increased supervision of antipoaching staff was found to improve their performance substantially (Jachmann, 2008). Adequate salaries and equipment are particularly crucial given the dangerous nature of the work: illegal hunters frequently resist arrest with violence and several incidents of serious assault of scouts occurred in the Conservancy during the study period. In Serengeti National Park in Tanzania increased investment in antipoaching reduced illegal hunting and achieved a reversal of declining trends of wildlife populations (Hilborn et al., 2006). An investment of USD $51 \mathrm{~km}^{-2}$ year ${ }^{-1}$ was required to reduce poaching levels to an acceptable level in Ghanaian parks (Jachmann, 2008). Expenditure on antipoaching in Savé Valley Conservancy varies from USD 2.76 to $118 \mathrm{~km}^{-2}$ year $^{-1}$, suggesting that a significant elevation in investment is required by some landowners to effectively manage illegal hunting.

Potential for under-reporting of illegal bushmeat hunting in protected areas In Gonarezhou official statistics suggest that pressure from illegal hunting is light. However, antipoaching effort in Gonarezhou at the time of our study (prior to the involvement of Frankfurt Zoological Society in management of the Park) was minimal and wildlife densities are lower than those in the adjacent Savé Valley Conservancy and Kruger National Park (Owen-Smith \& Ogutu, 2003; Joubert \& Joubert, 2008). This suggests that illegal hunting may have imparted greater impacts than realized by park management. Under-appreciation of the severity of illegal hunting may be a general phenomenon among African protected areas and probably encourages continued under-allocation of resources to address the problem. Illegal hunting probably contributes to the ongoing loss of species from African parks (Caro \& Scholte, 2007). In Tsavo National Park, for example, the Kenya Wildlife Service does not have a team dedicated to removing snares, despite their obvious prevalence (Wato et al., 2006).

\section{Conclusions}

Under conditions of widespread poverty, unemployment and food insecurity, illegal bushmeat hunting represents a severe threat to wildlife populations and wildlife-based land uses in the South-East Lowveld of Zimbabwe. Dramatic loss of wildlife populations followed settlement of game ranches during land reform and, without realignment of land uses or efforts to enable resettled farmers to engage in wildlife-based land uses, the prospects for conservation on private land are bleak. Our case study provides a number of widely applicable insights for the prevention and management of illegal bushmeat hunting. Anti-poaching efforts need to be aligned with the regular temporal and spatial patterns of illegal hunting. Leases for hunting and tourism concessions should ensure adequate investment by tourism operators in anti-poaching. In conservancies and hunting concessions minimum standards of per capita investment in anti-poaching should be met for landowners to qualify for legal hunting quotas. Reserve designers should minimize the perimeter to area ratio of parks. Fences should not be constructed using wire that can be made into snares. Land reform involving game ranches should integrate communities in wildlife-based land uses and ensure spatial separation between land for wildlife and human settlement. Means are required to enable communities to benefit from wildlife, to create disincentives for illegal hunting and to provide for more efficient use of wildlife resources. Further investigation into the scale and impacts of the bushmeat trade is required elsewhere in Southern Africa to provide a basis for the development of appropriate conservation strategies. 


\section{Acknowledgements}

We are grateful to TRAFFIC Southern and East Africa, the European Union, Wilderness Trust, Chicago Board of Trade and the supporters of the African Wildlife Conservation Fund for providing funding, Robert Burn for statistical advice, Rueben Bote and Mishek Matari for assistance with fieldwork, and the Savé Valley Conservancy for logistical support.

\section{References}

BARnes, R. (2002) The wild meat boom and bust in West and Central Africa. Oryx, 36, 236-242.

Barnett, R. (1998) Food for Thought: The Utilisation of Wild Meat in Eastern and Southern Africa. Traffic East/Southern Africa, Nairobi, Kenya.

Bennett, E., Blencowe, E., Brandon, K., Brown, D., Burn, R., Cowlishaw, G. et al. (2007) Hunting for consensus: reconciling wild meat harvest, conservation, and development policy in West and Central Africa. Conservation Biology, 21, 884-887.

Bотнма, J. (2002) Game Ranch Management. Van Schaik, Pretoria, South Africa.

Bowen-Jones, E. \& Pendry, S. (1999) The threat to primates and other mammals from the wild meat trade in Africa, and how this threat could be diminished. Oryx, 33, 233-246.

Bushmeat Crisis Africa. (2004) A Bloody Trade. Pan African Association of Zoos and Aquaria, Pretoria, South Africa. Http:// www.bushmeat.org.za/article5.htm [accessed 24 April 2009].

Caro, T. \& Scholte, P. (2007) When protection falters. African Journal of Ecology, 45, 233-235.

Caswell, H. (2001) Matrix Population Models: Construction, Analysis and Interpretation. 2nd ed. Sinauer Associates, Sunderland, USA.

Caswell, H. \& Weeks, D.E. (1986) Two-sex models: chaos, extinction, and other dynamic consequences of sex. American Naturalist, 128, 707-735.

Cumming, D. (2004) Performance of parks in a century of change. In Parks in Transition (ed. B. Child), pp. 105-124. Earthscan, London, UK

D A м M, G. (2005) Game sales statistics South Africa. African Indaba, $3,16-18$.

de Merode, E. \& Cowlishaw, G. (2006) Species protection, the changing informal economy, and the politics of access to the bushmeat trade in the Democratic Republic of Congo. Conservation Biology, 20, 1262-1271.

Dunham, K., Mackie, C., Musemburi, C., Zhuwau, G., Taylor, R. \& Chimuti, T. (2007) Aerial Survey of Elephants and Other Large Herbivores in Gonarezhou National Park. WWF-SARPO Occasional paper 18. WWF, Harare, Zimbabwe.

DU ToIT, R. (2004) Review of Wildlife Issues Associated with the Land Reform Programme in Zimbabwe. WWF-Southern African Regional Programme Office, Working Paper No. 10. WWF, Harare, Zimbabwe.

FA, J., Peres, C. \& Meeuwig, J. (2002) Wild meat exploitation in tropical forests: an intercontinental comparison. Conservation Biology, 16, 232-237.

GERBER, L.R. (2006) Including behavioural data in demographic models improves estimates of population viability. Frontiers in Ecology and the Environment, 4, 419-427.

Grossman, D. \& Holden, P. (2009) Towards transformation: contractual parks in South Africa. In Evolution \& Innovation in
Wildlife Conservation (eds H. Suich, B. Child \& A. Spenceley), pp. 357-372. Earthscan, London, UK.

Hilborn, R., Arcese, P., Borner, M., Hando, J., Hopcraft, G., Lогвоокі, M. et al. (2006) Effective enforcement in a conservation area. Science, 314, 1266.

JACHMANN, H. (2008) Illegal wildlife use and protected area management in Ghana. Biological Conservation, 141, 1906-1918.

JMPIN (2000) JMPIN v. 4.o.2. SAS Institute, Cary, USA.

Joubert, D. \& Joubert, L. (2008) Aerial Survey of the Savé Valley Conservancy, September 2007. Unpublished Report. Savé Valley Conservancy, Chiredzi, Zimbabwe.

Joubert, D. \& Joubert, L. (2009) Aerial Survey of the Savé Valley Conservancy, September 2008. Unpublished Report. Savé Valley Conservancy, Chiredzi, Zimbabwe.

LEWIS, D. (2007) Can wildlife and agriculture co-exist outside protected areas in Africa? A hopeful case-study in Zambia. In Bushmeat and Livelihoods (eds G. Davies \& D. Brown), pp. 177196. Blackwell, Oxford, UK.

LEWIS, D. \& PhIRI, A. (1998) Wildlife snaring-an indicator of community response to a community based conservation project. Oryx, 32, 111-121.

Lindsey, P. \& Bento, C. (2010) Illegal Hunting and the Bushmeat Trade in Central Mozambique: A Case Study from Coutada 9, Manica Province. TRAFFIC, Cambridge, UK.

Lindsey, P., Du Toit, R., Pole, A. \& Romañach, S. (2009) Savé Valley Conservancy: a large scale African experiment in cooperative wildlife management. In Evolution and Innovation in wildlife Conservation (eds H. Suich, B. Child \& A. Spenceley), pp. 163-184. Earthscan publishers, London, UK.

Lindsey, P.A., Romañach, S.S, Matema, S., Matema, C., Mupamhadzi, I., \& Muvengwi, J. (2011) Dynamics and underlying causes of the illegal bush-meat trade in South East Zimbabwe. Oryx, 45, 84-95.

Lindsey, P., Roulet, P. \& Romañach, S.S. (2007) Economic and conservation significance of the trophy hunting industry in sub-Saharan Africa. Biological Conservation, 134, 455-469.

Loibooki, M., Hofer, H., Campbell, K. \& East, M. (2002) Bushmeat hunting by communities adjacent to the Serengeti National Park, Tanzania: the importance of livestock ownership and alternative sources of protein and income. Environmental Conservation, 29, 391-398.

Mulombwa, J. (1998) Non-Wood Forest Products in Zambia. EC-FAO Report. EC-FAO, Kasama, Zambia. Ftp://ftp.fao.org/ docrep/fao/o03/X6701E/X6701Eoo.pdf [accessed 17 November 2008].

Ndibalema, V. \& Songorwa, A. (2007) Illegal meat hunting in Serengeti: dynamics in consumption and preferences. African Journal of Ecology, 46, 311-319.

Noss, A. (1998) The impacts of cable snare hunting on wildlife populations of the Central African Republic. Conservation Biology, 12, 390-398.

Okello, M. \& Kiringe, J. (2004) Threats to biodiversity and their implications in protected and adjacent dispersal areas of Kenya. Journal of Sustainable Tourism, 12, 55-69.

OWen-Smith, N. \& Mason, D.R. (2005) Comparative changes in adult vs juvenile survival affecting population trends of African ungulates. Journal of Animal Ecology, 74, 762-773.

Owen-Smith, N. \& OGutu, J. (2003) Rainfall influences on ungulate population dynamics. In The Kruger Experience: Ecology and Management of Savannah Heterogeneity (eds J. Du Toit, H. Biggs \& K. Rogers), pp. 310-331. Island Press, Washington, DC, USA. 
Pole, A. (1999) The behaviour and ecology of African wild dogs, Lycaon pictus, in an environment with reduced competitor density. $\mathrm{PhD}$ thesis. University of Aberdeen, Aberdeen, UK.

R Development Core Team (2008) R: A Language and Environment for Statistical Computing. R Foundation for Statistical Computing, Vienna, Austria. Http://www.R-project.org/ [accessed 21 July 2010].

Robinson, J. \& Bennett, E. (2004) Having your wildlife and eating it too: an analysis of hunting sustainability across tropical ecosystems. Animal Conservation, 7, 397-408.

VAughan, C. \& Long, A. (2007) Bushmeat, wildlife management and good governance: rights and institutional arrangements in Namibia's community based natural resource management. In Bushmeat and Livelihoods (eds G. Davies \& D. Brown), pp. 177196. Blackwell, Oxford, UK.

Wato, Y., Wahungu, G. \& Oкеllo, M. (2006) Correlates of wildlife snaring patterns in Tsavo West National Park, Kenya. Biological Conservation, 132, 500-509.

Wilkie, D. \& Carpenter, J. (1999) Bushmeat hunting in the Congo Basin: an assessment of impacts and options for mitigation. Biodiversity and Conservation, 8, 927-955.

Wilkie, D., Curran, B., Tshombe, R. \& Morelli, G. (1998) Modelling the sustainability of subsistence farming and hunting in the Ituri forest of Zaire. Conservation Biology, 12, 137-147.

\section{Appendix}

The appendix for this article is available online at http:// journals.cambridge.org

\section{Biographical sketches}

Peter A. Lindsey's research interests include sustainable utilization of wildlife, the bushmeat trade and developing incentives for land uses conducive to wildlife conservation. S TEPHANIE S. ROMAÑ ACH works on ecological modelling for restoration of the Everglades, USA, was previously involved in conservation projects in Southern and East Africa, remains involved with projects in Zimbabwe, and helps run the African Wildlife Conservation Fund. Craig J. TAmbling's research interests include predator-prey interactions in African ecosystems and the impact that these interactions have on the population dynamics of both prey and predators. KEVIN CHARTIER is a software developer specializing in applications for scientific research. His research interests include digital signal processing, software design frameworks and human-computer interaction. ROSEMARY GROOM currently runs the Lowveld wild dog project and conducts research on predators throughout south-east Zimbabwe. 